\title{
Études/Inuit/Studies
}

\section{BAUER, Stefan, Stefan DONECKER, Aline EHRENFRIED and Markus HIRNSPERGER (eds), 2005 Bruchlinien im Eis. Ethnologie des zirkumpolaren Nordens, Wien, LIT Verlag, Beiträge zum zirkumpolaren Norden / Contributions to Circumpolar Studies, 1, 316 pages.}

\section{Ludger Müller-Wille}

Volume 29, numéro 1-2, 2005

Préserver la langue et les savoirs

Preserving language and knowledge

URI : https://id.erudit.org/iderudit/013949ar

DOI : https://doi.org/10.7202/013949ar

Aller au sommaire du numéro

\section{Éditeur(s)}

Association Inuksiutiit Katimajiit Inc.

Centre interuniversitaire d'études et de recherches autochtones (CIÉRA)

ISSN

0701-1008 (imprimé)

1708-5268 (numérique)

Découvrir la revue

Citer ce compte rendu

Müller-Wille, L. (2005). Compte rendu de [BAUER, Stefan, Stefan DONECKER, Aline EHRENFRIED and Markus HIRNSPERGER (eds), 2005 Bruchlinien im Eis. Ethnologie des zirkumpolaren Nordens, Wien, LIT Verlag, Beiträge zum zirkumpolaren Norden / Contributions to Circumpolar Studies, 1, 316 pages.] Études/Inuit/Studies, 29(1-2), 345-347. https://doi.org/10.7202/013949ar d'utilisation que vous pouvez consulter en ligne. 


\section{Recensions / Book reviews}

\section{BAUER, Stefan, Stefan DONECKER, Aline EHRENFRIED and Markus HIRNSPERGER (eds) \\ 2005 Bruchlinien im Eis. Ethnologie des zirkumpolaren Nordens, Wien, LIT \\ Verlag, Beiträge zum zirkumpolaren Norden / Contributions to Circumpolar Studies, 1, 316 pages.}

Since the late 1980s research in social sciences and humanities in the circumpolar north has expanded thematically and geographically and experienced considerable changes and adaptations in methodologies and applications. These processes evolved from the collapse of the political and ideological bipolarity that had existed in the arctic and subarctic for some 70 years during the $20^{\text {th }}$ century. This bipolar isolation also had an impact on scientific endeavours in the northern circumpolar regions. These new developments allowed for energetic and innovative research initiatives that resulted in the emergence of the international research community of arctic social scientists within and outside the circumpolar north. Trans-cultural and trans-national institutions, associations, large-scale collaborative research schemes, individual long-term field studies, and academic study programs were founded and conducted which have shaped northern research at the beginning of the $21^{\text {st }}$ century.

An example of such initiatives is the Working Group Arctic and Subarctic (AASArbeitsgemeinschaft Arktis und Subarktis-http://www.sub-arctic.ac.at), which was established in 1997 by engaged graduate students and faculty at the University of Vienna, Austria. The disciplines represented within this working group include anthropology, linguistics, Slavic and Nordic studies. The working group has become a rallying point of young northern social scientists in Central Europe, who, over the coming years, have extended their networks internationally. Their geographical focus in the circumpolar north has mainly been on Siberia and the Russian European North.

In June 2000, the AAS brought together 24 social scientists and representatives of NGOs from Austria, almost half of them, Canada, Estonia, France, Germany, Japan, Norway, Russian Federation, and the USA to discuss their research conducted during the 1990s (Hirnsperger 2000). The book Bruchlinien im Eis-Ethnologie des zirkumpolaren Nordens (Crack Lines in the Ice. Ethnology of the Circumpolar North) presents the proceedings of this conference which consist of 19 contributions prefaced by Peter Schweitzer who is the editor of the newly established series Beiträge zum zirkumpolar347cumpolar Studies of which this book is the first volume. The introduction by the editorial team outlines the three thematic sections and the individual contributions; the sections' headings are Ethnicity; Economy and Ecology; and History of Science. Most of the contributions were written in German originally, however, several articles were apparently translated either from Russian, English or other languages. Unfortunately, the editors did not give an indication of this process and 
chose not to mention the translation and translators giving them proper recognition either individually or as a team.

The ambitions of the editorial team are similar to some earlier efforts to understand the social, economic, and ecological processes that have occurred throughout the circumpolar north (e.g., Berg 1973). The editors point out that it is not the aim of this compendium to cover and represent the circumpolar regions as a whole and evenly. Rather they stress that the examples discussed in the contributions, despite their geographical bias on northern Eurasia (i.e. mainly Siberia), serve as a base for further comparisons and interpretations within the expanding social sciences by highlighting specific common themes and issues. Because of the high quality of the various contributions, they are of interest to the readers of Études/Inuit/Studies although they fall outside the realm of this journal. Next to the contributions dealing with specific cases in the North of the Russian Federation, which are not reviewed here, there are two noteworthy contributions that touch upon the Inuit in the circumpolar North in Canada and Greenland.

Verena Traeger, Legal Conflict-Inughuit vs. Denmark (pp. 71-86), provides a succinct and well-documented analysis of the history of Inughuit-American-Danish relations in northern Greenland with respect to the displacement of Inughuit from their ancestral lands caused by the military base at Thule and to the ensuing legal struggle with the Danish government to maintain integrity and attain recognition and compensation. Although the legal recourse available to the Inughuit seems to be exhausted, relations continue to be strained, a reminder of the colonial heritage in Greenland. Traeger is fair in her assessment by pointing out that there are various positions taken with respect to the importance of indigenous rights or so-called public safety in the name of defending democracy (p. 85).

Andrea H. Procter, The Construction of Power Structures and Traditional Knowledge in Northern Canada (pp. 208-219), discusses some of the outcomes of the inclusion of "traditional ecological knowledge" (TEK) into environmental and socioeconomic impact assessment studies for development projects and into environmental protection laws in Canada. This inclusion into the legal system has resulted in new institutions and frameworks (e.g., co-management regimes or royalty sharing) in which aboriginal peoples have found that they have not attained the powers they had envisioned. Procter argues that policies and their implementation are controlled by external interests rather than by the aboriginal peoples themselves. She maintains that the approach by the Government of Nunavut to make the Inuit equivalent to TEK, Inuit Qaujimajatuqangit, part of laws and policies has yielded more promising results since it is directly built on the values of Inuit communities and their culture and language. This can be argued because, in 2005 , one still has to see how committed the public government of Nunavut is to stand behind such policies and laws and also dedicate the necessary funds so that these policies can be effective.

The book offers the reader a broad range of anthropological topics that are currently discussed within modern arctic social sciences. The editors are to be congratulated that they showed strong perseverance to see this volume through to 
publication. It is also hoped that the series started with this book will continue to publish pertinent scientific contributions. With good intentions, a similar series was begun in Germany in the 1990s, but did not get beyond the first volume (Kasten 1994). We have become used to rely on literature in English as an overwhelming linguistic denominator, it is therefore refreshing to peruse and review books published in other languages to allow the sharing of insights and understandings of different cultural processes.

\section{References}

BERG, Gösta (ed.)

1973 Circumpolar Problems. Habitat, Economy and Social Relations in the Arctic, (A Symposium for Anthropological Research in the North, September 1969), Oxford, Pergamon Press.

HIRNSPERGER, Markus (ed.)

2000 Conference: Siberia and the Circumpolar North. Contributions by Anthropologists and NGOs, Vienna, Working Group Arctic and Subarctic.

KASTEN, Erich (ed.)

1994 Ethnologische Beiträge zur Circumpolarforschung, Band 1, Berlin, Reinhold Schletzer Verlag.

Ludger Müller-Wille Department of Geography McGill University Montréal (Québec) H3A 1 Y1

Canada

ludger.muller-wille@mcgill.ca

BOAS, Norman F.

2004 Franz Boas 1858-1942. An Illustrated Biography, Mystic, Connecticut, Seaport Autographs Press, 292 pages.

This book is the first complete biography of Franz Boas written by his grandson, Norman F. Boas. The author states clearly that he intended to write an illustrated biography with a personal viewpoint expressed by Franz Boas' descendents. He does not aim at a critical scientific analysis of Boas' achievements. Still, Norman Boas presents succinctly Boas' scientific accomplishments and academic career and compliments his writings with much engaged personal insight into Franz Boas' personality as experienced by the extended Boas-Krackowizer family. The book is illustrated with a large number of private photos of Franz Boas, his family, and his research sites in the Canadian Arctic and British Columbia; some of these photos have never been published before. 